\title{
Incisive Fossa - Case Report
}

\author{
Fosa Incisiva - Reporte de un Caso
}

\author{
Nilton Alves
}

\begin{abstract}
ALVES, N. Incisive fossa- Case report. Int. J. Morphol., 28(3):921-922, 2010.
SUMMARY: The importance of the radiographic anatomy knowledge in the interpretation of the pathologies is undeniable. The base of this knowledge is a great familiarity with the anatomy of the region that is going to be evaluated. Thus, it is important to recognize what is considered normal, as well as the anatomical variations, so that one can identify what is pathologic. In this case report we describe a radiographic finding in leucoderm patient, 13 years old and one month, submitted to a panoramic radiography in a private clinic in São Paulo - Brazil, for evaluation of the third molars. During the radiographic reading, a bilateral radiolucid area with an inverted tear shape could be observed in the region between the roots of the lateral incisive teeth and upper canines. Although it was an image that suggested bone rarefaction, the integrity of the hard lamina was evident in both sides. During the patient's clinical examination, a bilateral asymmetry was not observed, as well as any kind of sintomatology. In our case report, according to the clinical and radiographic findings, we conclude that the diagnosis was bilateral incisive fossa.
\end{abstract}

\section{KEY WORDS: Incisive fossa; Radiographic anatomy; Bone rarefaction.}

\section{INTRODUCTION}

The importance of the radiographic anatomy knowledge in the interpretation of the pathologies is undeniable. The base of this knowledge is a great familiarity with the anatomy of the region that is going to be evaluated. Thus, it is important to recognize what is considered normal, as well as the anatomical variations, so that one can identify what is pathologic. We should also consider that the radiography is the projection of tridimensional images in a bidimensional surface, determining a structure superposition, and also a change in the shape and dimension of the object (Antoniazzi et al., 2008). All these factors should be considered during the reading of the images.

\section{CASE REPORT}

Leucoderm patient, male, 13 years old and a month, submitted to a panoramic radiography in a private clinic in São Paulo- Brazil, for evaluation of the third molars.

During the radiographic reading, a bilateral radiolucid area with an inverted tear shape could be observed in the maxilla's alveolar process between the roots of the lateral incisive teeth and canine teeth (Fig. 1). Although it was an image that suggested bone rarefaction, the integrity of the hard lamina was evident in both sides.

During the patient's clinical examination, a bilateral asymmetry was not observed, neither was any kind of sintomatology.

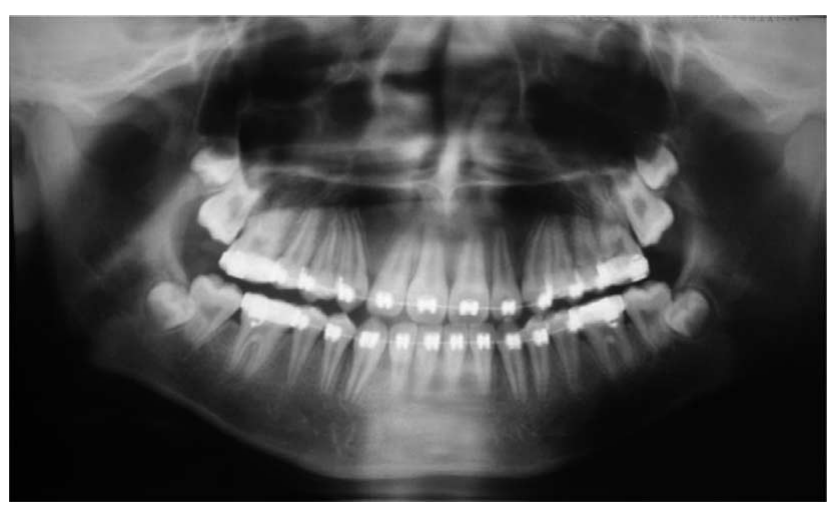

Fig. 1 Panoramic radiography showing a bilateral radiolucid area with an inverted tear shape in the maxilla's alveolar process between the roots of the lateral incisive teeth and canine teeth. 


\section{DISCUSSION}

It is undeniable that the anatomic knowledge is crucial in all the clinical subjects. In radiology, it is the knowledge of the normal anatomy and the anatomic variations that allows us to recognize the pathologic changes. Regarding the odontological radiology, the base for the radiographic reading is the bone anatomic knowledge of the maxilla and mandible (Bernaerts $e t$ al., 2006).

We know that the bone tissue, due to its plasticity, is capable to adapt to the functional demands to which it is submitted, and can also suffer alterations due to metabolic changes. Thus, at physiological levels, there is a constant bone remodeling. These changes, however, can be stimulated by pathologic agents, setting more intense answers that cause changes that can be recognized through radiography.

Alterations that can be recognized through radiography are the aim of the interpretation for diagnostic purposes (Antoniazzi et al.).

The radiography comprehends the projection of three dimensional images at a bi dimensional surface, causing an overposition of structures and changes in the shape and dimension of the object. Such factors should be of previous knowledge when reading the images. Some authors also call the attention to the fact that the pathologic alterations will come together with the normal anatomic images, what can make the interpretation a little confusing (Antoniazzi et al.).

The incisive fossa (or myrtiform fossa) corresponds to an area of the maxilla's alveolar process between the roots of the lateral incisive teeth and the canine teeth, where there is the prevalence of medullar spaces and little trabeculae bone. This characteristic can be observed only through the radiography and is present in few patients. Thus, we agree with Lundeen \& Barnett (1994), when they say that the bone in the region of the lateral incisive and canine can have a more radiolucid appearance, due to its slenderness, which could lead the observer to view it as a bone rarefaction. Therefore, the incisive fossa deserves attention during the radiographic interpretation once its radiolucid appearance can be taken as a bone rarefaction.

In these cases, it is important to evaluate the clinical symptomatology, as well as to check the integrity of the hard lamina and its symmetry when compared to the opposite side (Moreira, 2000).

It is also interesting to remember that a precise diagnosis involves not only of the anatomy's knowledge of the region, but also of the pathology and the other resources available to obtain the image, such as the localization radiographyc methods and tomographies.

In our case report, according to the clinical and radiographic findings, we conclude that the diagnosis was bilateral incisive fossa.

ALVES, N. Fosa incisiva - Reporte de un caso. Int. J. Morphol., 28(3):921-922, 2010.

RESUMEN: La importancia de los conocimientos de anatomía radiográfica en la interpretación de las patologías es innegable. La base de este conocimiento es familiarizarse con la anatomía de la región que va a ser evaluada. Por tanto, es importante reconocer lo que se considera normal, así como las variaciones anatómicas y, de esta manera, identificar lo que es patológico. En este caso clínico, se describe un hallazgo radiológico en un paciente leucodérmico, de 13 años y un mes de edad, quiense realizó, para la evaluación de los terceros molares, una radiografía panorámica en una clínica privada en São Paulo - Brasil. Durante la lectura radiológica, se pudo observar en la región entre las raíces de los dientes incisivos laterales y caninos superiores una zona radiolúcida bilateral con una forma de lágrima invertida. Aunque era una imagen que sugería rarefacción ósea, la integridad de la lámina dura se hizo evidente en ambos lados. Durante la exploración clínica del paciente, no se observó una asimetría bilateral, así como cualquier tipo de sintomatología. En este caso, de acuerdo con los hallazgos clínicos y radiográficos, se concluye que el diagnóstico es la presencia de una fosa incisiva bilateral.

PALABRAS CLAVE: Fosa incisiva; Anatomía radiográfica; Rarefacción ósea.

\section{REFERENCES}

Antoniazzi , M. C. C.; Carvalho, P. L. \& Koide, C. H. Importância do conhecimento da anatomia radiográfica para a interpretação de patologias ósseas. $R B O, 56(2): 195-9,2008$.

Bernaerts, A.; Vanhoenacker, F.M.; Geenen, L.; Quisquater, G. \& Parizel, P. M. Conventional dental radiology: what the general radiologist needs to know. JBR-BTR, 89(1):23-32, 2006.

Lundeen, R. C. \& Barnett, D. A. Radiolucencies with indistinct or ragged borders. Dent. Clin. North. Am., 38(1):83-112, 1994.

Moreira, C.A. Diagnóstico por imagem em Odontologia. São Paulo: Robe Editorial, 2000.

\author{
Correspondence to: \\ Nilton Alves \\ Departamento de Ciencias Básicas y Biomédicas \\ Facultad de Ciencias de la Salud \\ Oficina 104 Anatomía. Avenida Lircay s/n, Talca \\ Universidad de Talca \\ CHILE
}

Email: niltonnalves@yahoo.com.br

Received: 22-01-2010

Accepted: 11-03-2010 